\title{
Activity Test and Inhibitory Mechanism of Essential Oil of Lime Leaf (Citrus Aurantifolia, Swingle) Against Some of Bacterial Pathogens
}

\author{
Muhammad Yanis Musdja ${ }^{a^{*}}$, Arys Medta Pariwidjayanti ${ }^{b}$, Andria Agusta ${ }^{c}$ \\ ${ }^{\mathrm{a}, \mathrm{b}}$ Department of Pharmacy, Faculty of Medicine and Health Sciences, State Islamic University, Jakarta, \\ ${ }^{\mathrm{c}}$ Indonesian Institute of Sciences, Cibinong, Bogor. \\ *Email: myanis88@gmail.com
}

\begin{abstract}
Lime fruit (Citrus aurantifolia Swingle) is traditionally known to be useful for the treatment of various infectious diseases like fever, cough, toothache, sore throat, diphtheria, body odor, ringworm etc as folk medicine. Objectives: This study aims to determine the activity and mechanism of inhibition of the growth of some bacterial pathogens by the essential oil of lime leaves (Citrus aurantifolia, swingle). Materials and Methods: The lime leaves was obtained from Balitro Bagor, distilled by steam distillation process. The essential oil of lime leaf that obtained was analyzed by Gas Chromatography-Mass Spectroscopy. The activity test of anti-bacterial of essential oil of lime leaves was carried out by using the method mikrodilution against the bacterium Staphylococcus epidermidis, Staphylococcus aureus, Escherichia coli, Micrococcus luteus and Bacillus subtilis. For detect the mechanism of cell damage process of bacteria was observed leakage of proteins and nucleic acids by using Ultra Violet-Visible spectrophotometer and the leakage of cations $\mathrm{K}^{+}$and $\mathrm{Ca}^{2+}$ was observed by using Atomic Absosrtion Spectrum. While bacterial cell morphology change was observed by using Scanning Electron Microscope (SEM). Results and Conclusion: From the research was obtained, Lime leaf contains about $0.4 \%(\mathrm{v} / \mathrm{w})$ essential oils with the main components are geranial $(10.39 \%)$, limonene $(10.2 \%)$, neral $(8.94 \%)$, kariofilena $(5.72 \%)$ and citronellal $(5.41 \%)$. The essential oil of lime leaf has the highest antibacterial activity on the bacteria tested was on Bacillus subtilis, with a minimum inhibitory concentration (MIC) of $0.125 \%(\mathrm{v} / \mathrm{v})$. Test results nucleic acid and protein leakage and cations leakage of $\mathrm{K}^{+}$and $\mathrm{Ca}^{2+}$ greatly increased from $1 \mathrm{MIC}$ to 2 MIC concentration of the tested bacteria compared with the normal controls. While the observations that was detected by using Scanning Electron Microscope (SEM) showed worse cell damage by giving the higher doses to bacteria.
\end{abstract}

Keyword: Essential oil of lime leaf, Antibacterial, Staphylococcus epidermidis, Staphylococcus aureus, Escherichia coli, Micrococcus luteus, Bacillus subtilis.

\section{Introduction}

Medicinal plants are promising resources. The use of medicinal plants as screening pool for novel antibiotics has several advantages related to safety, availability, and minimizing the risk ofside ef[ects and addiction The World Health Organization adopted major policy change in accepting that most developing nations would have to make use of more traditional medical practices for primary health care [1].

Recently, microbial infections have become a major international health problem. The conventionally used antibiotics are losing their efficacy against the pathogens. Development of multidrug resistance among the pathogenic microbes has forced the scientific community to search for new antimicrobial compounds from alternative sources such as medicinal plants [2].

Acid lime or Citrus aurantifolia (Christm) Swingle (family: Rutaceae) is a well-known medicinal and food plant. It is widely cultivated around the world; and almost all parts of this plant are used in traditional medicine as preserves, astringent, diuretic, insect repellent, antiseptic, and antimicrobial for treatment of gastrointestinal ailments, cough, colds and sore throat, acne, asthma, chilblains, colds, dull skin, flu, varicose veins [3, 4] and also citral oil is extracted for use in perfumes [5]

The organic acid component of acid lime juice is primarily composed of citric acid. The soluble solid of the juice consist mainly of sugar and citric acid. The total acid content in acid lime is varied ranges from 5\%-7.5\% and total soluble solid $5.5 \%-8.5 \%$ [6].

The acid content in juice plays an important role in determining the quality of a variety as well as maturity indices of fruit [7]. In citrus species, amount of organic acid is genetically controlled [8]. In his report, a seedless variety of lime is content $60-66$ percent juice, vitamin $\mathrm{C}$ (ascorbic acid) $118.2-140.8 \mathrm{mg} / 100 \mathrm{~g}$ and citric acid $8.3 \%$ - 9.1\%. Ascorbic acid is one of the most important vitamins found in acid lime juices. The main contribution of citrus fruits in human nutrition is undoubtedly their supply of vitamins especially ascorbic acid. Daily vitamin $\mathrm{C}$ intake $5 \mathrm{mg}$ is sufficient to prevent the symptoms of scurvy in an adult [9], but requirements of vitamin $\mathrm{C}$ was estimated of $30-60 \mathrm{mg}$ for full grown adult and an orange a day can fulfill this requirement and ensure good health. Amount of ascorbic acid, juice, TSS and TA contents is influenced by variety, cultural practice, maturity, climate, fruit growth stage and bearing side of the tree [10]. 
Physicochemical composition of lime fruits like juice, TSS, TA and vitamin $\mathrm{C}$ is the important parameter to determine the quality, which may be influenced by the climate, altitude, temperature, soil and bearing sides of the trees. Fruiting side of the tree is one of the important factors that determined the quality of fruits. Producers, consumers and traders have a very limited knowledge in this aspect. It is necessary tostudy the variation of fruit quality at different side of the tree for rocessing and marketing. Therefore, the main objectives of this study is to determined the concentration of vitamin C, TSS, TA and juice percent of lime fruitsat different sides of the tree. Findings of the study will help to select the best quality of lime fruits for commercialization and industrial uses[11].

\section{Objectives}

Study the antibacterial activity and the inhibitory form by the essential oil of lime leaves against several types of bacteria

\section{Materials}

The essential oil of lime leaves (Citrus aurantifolia) is obtained from Indonesian Agency for Agricultural Research and Development, tween 80, ethanol $95 \%$, medium Nutrien Agar (NA), medium Mueller Hinton Agar (MHA), medium Mueller Hinton Broth (MHB), paper disc, phosphate buffer, sterile aquadest, iodonitrotetrazolium, $2 \%$ glutaraldehyde, cocodilate buffer, $1 \%$ osmium tetraoxide, $70 \%$ alcohol, $80 \%$ alcohol, $90 \%$ alcohol and gold.

The bacteria used were Staphylococcus aureus (NBRC 14276), Escherichia coli (NBRC 14237), Micrococcus luteus (NBRC 14218) and Bacillus subtilis (NBRC 3134) obtained from the Microbiology Laboratory, Indonesian Institute of Sciences, Staphylococcus epidermidis obtained from the Laboratory of Faculty Microbiology Medicine, University of Indonesia.

\section{Research Method}

\section{a. Distillation of Essential Oils of Lime Leaf}

Lime leaves of $3.1 \mathrm{~kg}$ are distilled using steam and water for 6 hours. The resulting volatile oil is collected, then released from the airk content by adding anhydrous sodium sulfate, and then weighed for the determination of the oil content obtained.

\section{b. Determination of Essential Oil Component of lime leaves}

Chemical components of essential oil compound were analyzed by Gas Chromatography-Mass Spectrometry (GC-MS, Saturn 2000, Varian) with injection volume of 5 $\mu 1$. The columns used were VF-17 MS (length: $30 \mathrm{~m}$, diameter, $0.25 \mathrm{~mm}$ ), carrier gas was helium with a flow rate of $1.3 \mathrm{ml} / \mathrm{min}$ and a column pressure of 10.7 Psi. The column temperature is programmed from $50{ }^{\circ} \mathrm{C}$ to $250{ }^{\circ} \mathrm{C}$ with 2 increment stages. In the initial stages the column temperature is kept constant $500{ }^{\circ} \mathrm{C}$ for $3 \mathrm{~min}$, then raised to $150{ }^{\circ} \mathrm{C}$. At a temperature of $150{ }^{\circ} \mathrm{C}$ then raised to 250 ${ }^{\circ} \mathrm{C}$. The condition at $250{ }^{\circ} \mathrm{C}$ was maintained for 3.67 minutes. The temperature of the injector during the analysis takes place in a programmed constant at a temperature of $230{ }^{\circ} \mathrm{C}$. The mass spectra of each peak of the GC-MS chromatogram compound were further compared to the authentic mass spectra found in the NIST (National Institute of Standard Technology) bank data.

\section{c. Determination of the Diameter of Zone Inhibition}

Determination of antibacterial activity of essential oil of lime leaves on Staphylococcus aureus, Staphylococcus epidermidis, Escherichia coli, Micrococcus luteus, us subtilis was done by agar diffusion method, using paper disc. Media for $20 \mathrm{~mL}$ of melted MHA is poured into sterile petri dishes and allowed to become solid. After solidification, the suspension of each bacteria of $0.1 \mathrm{~mL}$ is spread to the surface in order to be evenly distributed on different dishes. The sterile disc paper is placed on the agar medium and drops a test solution of $10 \mu \mathrm{l}$. For negative control, $10 \mu \mathrm{L}$ methanol solvent was used in each test bacterium. Each petri dish was incubated at $37{ }^{\circ} \mathrm{C}$ for 24 hours. Antibacterial activity was observed based on the diameter of the inhibitory area formed around the disc paper. Testing is done by duplo.

\section{d. Determination of MIC (Minimum Inhibitor Concentration)}

Determination of MIC essential oil was done by microdilution method using test tube. In each test tube was added $200 \mathrm{ul}$ medium MHB, $200 \mu 1$ suspension of Bacillus subtilis and $100 \mu \mathrm{L}$ concentration of essential oil at $1.25 \%$, $0.63 \%, 0.32 \%, 0.16 \%, 0.08 \%, 0,04 \%$ and $0.02 \%$. Then the dishaker incubator at $37^{\circ} \mathrm{C}$ at $144 \mathrm{rpm}$ for 18 hours. After the incubation process, $100 \mu$ of each mixture was piped into a sterile microplate and given $14 \mu \mathrm{l}$ indicator iodonitrotetrazolium (INT) to determine the growth of bacteria marked by the color change to red. For control use four kinds of control that are :

1. Media control, contains only $500 \mu 1$ of MH broth media

2. Negative control, containing $400 \mu \mathrm{l}$ of $\mathrm{MH}$ Broth medium and $100 \mu \mathrm{l}$ of solvent ( $2 \%$ ethanol, tween 80 $0,5 \%$ and aquadest)

3. Bacterial control, containing $300 \mu \mathrm{l}$ of medium and 200 $\mu 1$ of bacterial suspension

4. Solvent control, containing $200 \mu \mathrm{l}$ of medium, $200 \mu \mathrm{l}$ of bacterial suspension and $100 \mu \mathrm{l}$ of solvent $(2 \%$ ethanol, tween $800,5 \%$ and aquadest)

From the procedure obtained MIC value of essential oil of lime leaves. The MIC value is expressed as the smallest concentration of essential oil of lime leaves which can inhibit the growth of test bacteria.

\section{e. Analysis of Protein Leakage and Nucleic Acid}

Cell leak analysis was performed using a spectrophotometer and absorbance measurements were performed at $260 \mathrm{~nm}$ wavelength (for nitrogen content of nucleic acids) and $280 \mathrm{~nm}$ wavelength (for nitrogen content of proteins). Suspension of test bacteria as much as $10 \mathrm{ml}$, which has been grown for 24 hours in MHB media, centrifuged at $3500 \mathrm{rpm}$ for 20 minutes. The filtrate was removed and the cell deposit was suspended with $9 \mathrm{ml}$ of phosphate buffer $\mathrm{pH}$ 7.0. Added essential oil of lime leaf with dose of $1 \mathrm{MIC}, 2 \mathrm{MIC}$ and control, incubated in shaker incubator for 24 hours. After incubation, the 
suspension was centrifuged at $3500 \mathrm{rpm}$ for $15 \mathrm{~min}$, then filtered to separate the supernatant from the cell. Supernatant fluids were taken and measured their absorbance at $260 \mathrm{~nm}$ and $280 \mathrm{~nm}$ wavelengths using a UV spectrophotometer. The bacterial pellet was collected to be photographed with SEM by treatment in procedure (h) in below $[12,13]$

\section{f. Analysis Leak of Ion-Metal [12, 13]}

For leakage analysis the ions are measured in the form of $\mathrm{Ca}^{2+}$ and $\mathrm{K}^{+}$ions which exit from the bacterial cell membrane due to the treatment with the essential oil of lime leaves. Leakage of $\mathrm{Ca}^{2+}$ and $\mathrm{K}^{+}$ions is detected by using AAS. Samples for analysis of leakage of metal ions in the form of supernatant fluid derived from treatment in procedure (f).

\section{g. Analysis of Cell Morphological Changes $[12,13]$}

Pellet bacteria derived from treatment procedure 4.3.5 soaked with glutaral dehid and buffer cocodhilate for 4 hours. Furthermore, in centrifuge and supernatant discharged, the pellet is soaked with $1 \%$ tannin acid in chocodilate buffer for 12 hours. Subsequently centrifuged and the supernatant was removed, the pellet was immersed in $2 \%$ osmium tetraoxide solution for 2-4 hours. Then washed with cocodilate buffer, centrifuged and discarded supernatant. Pellets were washed with $50 \%$ cold ethanol, left for 10 minutes, centrifuged for 5 minutes then discarded supernatant. Pellets were washed back with $50 \%, 70 \%, 80 \%$ and $95 \%$ ethanol respectively for 10 minutes. Then washed with absolute ethanol and centrifuged for 5 minutes 2 times and washed again with butanol 2 times. Slightly tert-butanol is added to the cell precipitate and the smear of the cell is smeared on a glass slip. The glass slip used was washed first with absolute ethanol and in vacuum then stored at $-20^{\circ} \mathrm{C}$ for 12 hours. Glass slips that have been smeared with cells, coated with gold for 1 hour under vacuum and observed using JSM5310LV electron microscope.

\section{Results And Discussion}

a. Result of Distillation

The result of distillation of steam of essential oil of lime leaves was obtained yellow essential oil with distinctive aroma. with a concentration of $0.4 \%(\mathrm{v} / \mathrm{w})$ of wet weight of lime leaves.

b. Identification of Essential Oil Component of Lime Leaf

The GC-MS analysis showed that the essential oil of lime leaves has 40 chemical components as shown in Table 1. with 5 chemical components having content above $5 \%$. The five chemical components are geranial $(10,39 \%)$, limonena $(10,2 \%)$, neral $(8,94 \%)$, kariofilena $(5,72 \%)$ and citronellal $(5,41 \%)$. However, in these essential oils there are four chemical components not identified with the database used and covering about $5.82 \%$ of the total chemical components detected. 40 chemical components are then classified into 6 groups namely monoterpen, monoterpen alcohol, monoterpen aldehid, seskuiterpen, seskuiterpen alcohol and others, as shown in table 2 .

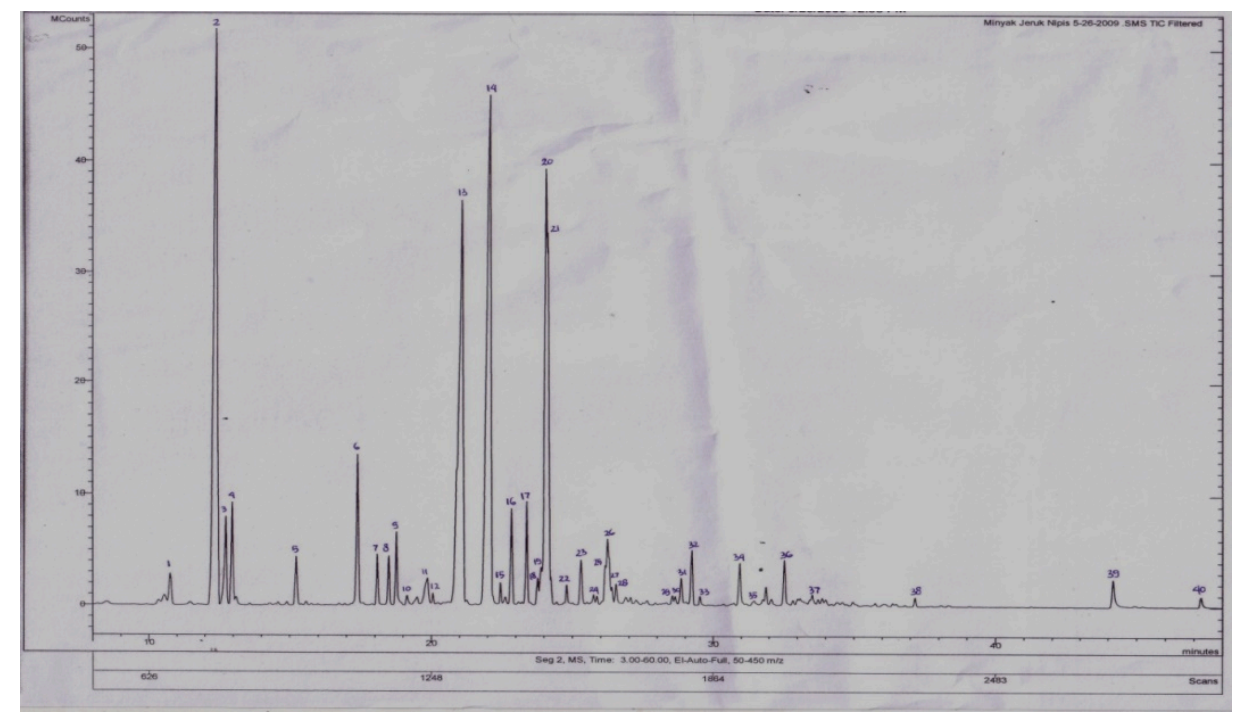

Figure 1. GC-MS Chromatogram essential oil of lime leaves 
Table 1. Essential oil components of lime leaves

\begin{tabular}{|c|c|c|c|c|c|}
\hline No. & $\begin{array}{c}\text { Retention } \\
\text { Time }\end{array}$ & Chemical Components & $\begin{array}{l}\text { Molecular } \\
\text { Formulas } \\
\end{array}$ & $\begin{array}{c}\text { Molecular } \\
\text { Weight }\end{array}$ & $\begin{array}{c}\text { Relative } \\
\text { Percentage }\end{array}$ \\
\hline 1. & 10,764 & 2- $\beta$-Pinena & $\mathrm{C}_{10} \mathrm{H}_{16}$ & 136 & $1,27 \%$ \\
\hline 2. & 12,432 & dl-Limonena & $\mathrm{C}_{10} \mathrm{H}_{16}$ & 136 & $10,20 \%$ \\
\hline 3. & 12,745 & Linalil asetat & $\mathrm{C}_{12} \mathrm{H}_{20} \mathrm{O}_{2}$ & 196 & $3,64 \%$ \\
\hline 4. & 12,971 & 1,3,6-Oktatriena,3,7-dimetil & $\mathrm{C}_{10} \mathrm{H}_{16}$ & 136 & $3,16 \%$ \\
\hline 5 . & 15,239 & $\begin{array}{c}\text { Bicyclo }(2,2,1) \text { Heptan-2-ol, 1,3,3- } \\
\text { trimetil-asetat }\end{array}$ & $\mathrm{C}_{12} \mathrm{H}_{20} \mathrm{O}_{2}$ & 196 & $1,74 \%$ \\
\hline 6. & 17,411 & Sitronelal & $\mathrm{C}_{10} \mathrm{H}_{18} \mathrm{O}$ & 154 & $5,41 \%$ \\
\hline 7. & 18,095 & $\begin{array}{c}\text { Bisiklo }(3,1,1) \text { Hep-2-en-2-ol, 4,6,6- } \\
\text { trimetil-[1S- (1-alpha, } 2 \text { beta, } 5 \\
\text { alpha)] }\end{array}$ & $\mathrm{C}_{10} \mathrm{H}_{16} \mathrm{O}$ & 152 & $1,52 \%$ \\
\hline 8. & 18,502 & Isopulegol & $\mathrm{C}_{10} \mathrm{H}_{18} \mathrm{O}$ & 154 & $1,47 \%$ \\
\hline 9. & 18,772 & Cis-Limonena oksida & $\mathrm{C}_{10} \mathrm{H}_{16} \mathrm{O}$ & 152 & $2,44 \%$ \\
\hline 10. & 19,143 & $\alpha$ - Terpinenil asetat & $\mathrm{C}_{12} \mathrm{H}_{20} \mathrm{O}_{2}$ & 196 & $1,26 \%$ \\
\hline 11. & 19,865 & $\alpha$-Fensil asetat & $\mathrm{C}_{12} \mathrm{H}_{20} \mathrm{O}_{2}$ & 196 & $1,63 \%$ \\
\hline 12. & 20,061 & Benzena Isosianometil & $\mathrm{C}_{8} \mathrm{H}_{7} \mathrm{~N}$ & 117 & $1,06 \%$ \\
\hline 13. & 21,123 & Neral & $\mathrm{C}_{10} \mathrm{H}_{16} \mathrm{O}$ & 152 & $8,94 \%$ \\
\hline 14. & 22,112 & Geranial & $\mathrm{C}_{10} \mathrm{H}_{16} \mathrm{O}$ & 152 & $10,39 \%$ \\
\hline 15. & 22,465 & Iso-Metil asetat & $\mathrm{C}_{12} \mathrm{H}_{22} \mathrm{O}_{2}$ & 198 & $1,91 \%$ \\
\hline 16. & 22,864 & $\beta$-Elemena & $\mathrm{C}_{15} \mathrm{H}_{24}$ & 204 & $3,17 \%$ \\
\hline 17. & 23,401 & Isopulegil asetat & $\mathrm{C}_{12} \mathrm{H}_{20} \mathrm{O}_{2}$ & 196 & $3,16 \%$ \\
\hline 18. & 23,777 & $\alpha$-Bergamotena & $\mathrm{C}_{15} \mathrm{H}_{24}$ & 204 & $0,84 \%$ \\
\hline 19. & 23,903 & Tetradekanal & $\mathrm{C}_{14} \mathrm{H}_{28} \mathrm{O}$ & 212 & $1,40 \%$ \\
\hline 20. & 24,097 & Kariofilena & $\mathrm{C}_{15} \mathrm{H}_{24}$ & 204 & $5,72 \%$ \\
\hline 21. & 24,159 & Tidak teridentifikasi & - & - & $2,32 \%$ \\
\hline 22. & 24,799 & Phenol, 4-etenil-2-metoksi & $\mathrm{C}_{9} \mathrm{H}_{10} \mathrm{O}_{2}$ & 150 & $1,84 \%$ \\
\hline 23. & 25,303 & $\alpha$-Humulena & $\mathrm{C}_{15} \mathrm{H}_{24}$ & 204 & $1,66 \%$ \\
\hline 24. & 25,867 & $(\mathrm{z}, \mathrm{z})-\alpha-$ Farnesena & $\mathrm{C}_{15} \mathrm{H}_{24}$ & 204 & $0,64 \%$ \\
\hline 25. & 26,243 & $\begin{array}{c}\text { 2,4A,8,8-Tetrametil- } \\
\text { 1,1A,4,4A,5,6,7,8-Oktahidro- } \\
\text { siklopropa Naptalena }\end{array}$ & $\mathrm{C}_{15} \mathrm{H}_{24}$ & 204 & $3,20 \%$ \\
\hline 26. & 26,305 & $\beta$-Selinena & $\mathrm{C}_{15} \mathrm{H}_{24}$ & 204 & $1,01 \%$ \\
\hline 27. & 26,397 & $\begin{array}{c}\text { 2-Isoprenil-4a, 8-dimetil- } \\
1,2,3,4,4 \mathrm{a}, 5,6,8 \mathrm{a} \text {-oktahidronaptalena }\end{array}$ & $\mathrm{C}_{15} \mathrm{H}_{24}$ & 204 & $1,49 \%$ \\
\hline 28. & 26,541 & $\alpha$-Selinena & $\mathrm{C}_{15} \mathrm{H}_{24}$ & 204 & $2,40 \%$ \\
\hline 29. & 28,541 & Veridiflorol & $\mathrm{C}_{15} \mathrm{H}_{26} \mathrm{O}$ & 222 & $0,94 \%$ \\
\hline 30. & 28,644 & Tidak teridentifikasi & - & - & $0,87 \%$ \\
\hline 31. & 28,854 & $\begin{array}{c}\text { 5- } \alpha \text {-Hidroksi-4 } \alpha, 8,10,11 \text { - } \\
\text { tetrametiltrisiklo }(6.3 .0 .0(2,4)) \text { undek- } \\
10 \text {-ena }\end{array}$ & $\mathrm{C}_{15} \mathrm{H}_{24} \mathrm{O}$ & 220 & $0,85 \%$ \\
\hline 32. & 29,236 & gamma-Gurjunena & $\mathrm{C}_{15} \mathrm{H}_{24}$ & 204 & $1,91 \%$ \\
\hline 33. & 29,528 & Tidak teridentifikasi & - & - & $1,10 \%$ \\
\hline 34. & 30,952 & Aromadendrena oksida & $\mathrm{C}_{15} \mathrm{H}_{24} \mathrm{O}$ & 220 & $1,61 \%$ \\
\hline 35. & 31,895 & $\begin{array}{c}\text { 1,3-Benzodioksol,4-Metoksi-6-(2- } \\
\text { Propenil) }\end{array}$ & $\mathrm{C}_{11} \mathrm{H}_{12} \mathrm{O}_{3}$ & 192 & $1,68 \%$ \\
\hline 36. & 32,554 & Spatulenol & $\mathrm{C}_{15} \mathrm{H}_{24} \mathrm{O}$ & 220 & $1,64 \%$ \\
\hline 37. & 33,535 & Kubenol & $\mathrm{C}_{15} \mathrm{H}_{26} \mathrm{O}$ & 222 & $0,70 \%$ \\
\hline 38. & 37,165 & $\begin{array}{l}\text { Phenol, 5-(1,5-dimetil-4-heksenil)-2 } \\
\text { metil }\end{array}$ & $\mathrm{C}_{15} \mathrm{H}_{22} \mathrm{O}$ & 218 & $1,09 \%$ \\
\hline 39. & 44,169 & $\begin{array}{l}\text { 3,7,11,15-Tetrametil-2-heksabodesen- } \\
\text { 1-ol }\end{array}$ & $\mathrm{C}_{20} \mathrm{H}_{40} \mathrm{O}$ & 296 & $1,19 \%$ \\
\hline 40. & 47,249 & Tidak teridentifikasi & - & - & $1,53 \%$ \\
\hline \multicolumn{5}{|c|}{ Total } & $100 \%$ \\
\hline
\end{tabular}


Table 2. Classification of essential oil components

\begin{tabular}{|l|l|l|}
\hline No. & Group Compounds & Amount \\
\hline 1 & Monoterpena & $14,63 \%$ \\
\hline 2 & Monoterpen Alcohol & $2,99 \%$ \\
\hline 3 & Monoterpen Aldehid & $24,74 \%$ \\
\hline 4 & Sesquiterpen & $22,04 \%$ \\
\hline 5 & Sesquiterpen Alcohol & $5,22 \%$ \\
\hline 6 & Others & $24,56 \%$ \\
\hline 7 & Not identified & $5,82 \%$ \\
\hline & Total & $100 \%$ \\
\hline
\end{tabular}

c. Test Result of Antibacterial Activity of Essential Oil of Lime Leaf

The antibacterial activity of essential oil of lime leaves on five bacteria can be calculated by measuring the Diameter of Zone Inhibition of bacterial growth around the clear-looking disc paper. Based on the test results presented in Table 3 it can be seen that volatile oil at $50 \%$ concentration can affect the growth of the five bacteria with different levels of resistance.

Bacillus subtilis has the highest level of sensitivity to the essential oil of lime leaves compared to the other four bacteria. This is evident from the measurement of the diameter of zone inhibitory, where Bacillus subtilis bacteria form the largest obstacle area, ie $31 \mathrm{~mm}$ compared with the other four bacteria essential oil of lime leaves. Based on the results of the research, it is found that the main components of $\gamma$-terpenena $(10,52 \%)$, geranial (7.25\%), neral (5.4\%) and Trans-2 hexane-1-al (5.04\%). When compared with Fadel's research [14], there are several equations of the chemical components of the essential oil of lime leaf (content above 5\%) consist of limonene compound $(23,88 \%), \beta$-pinena $(20,06 \%)$.

Table 3. Activity of essential oil of lime leaves on 5 bacteria at concentration $50 \%$

\begin{tabular}{|l|l|l|}
\hline No & Bacterial Test & Diameter Inhibition (mm) \\
\hline 1 & $\begin{array}{l}\text { Staphylococcus } \\
\text { epidermidis }\end{array}$ & $10 \mathrm{~mm}$ \\
\hline 2 & $\begin{array}{l}\text { Staphylococcus } \\
\text { aureus }\end{array}$ & $26 \mathrm{~mm}$ \\
\hline 3 & Escherichia coli & $8 \mathrm{~mm}$ \\
\hline 4 & Micrococcus luteus & $17 \mathrm{~mm}$ \\
\hline 5 & Bacillus subtilis & $31 \mathrm{~mm}$ \\
\hline 6 & Methanol control & Negative \\
\hline
\end{tabular}

\section{d. Determination of MIC}

The determination of MIC values is based on the minimal concentration of essential oil of lime leaves which can inhibit the growth of Bacillus subtilis. Based on the test results obtained MIC value of essential oil of lime leaves of $0.125 \%$ as shown in table 4 .

Table 4. Determination of MIC value of essential oil of lime leaves

\begin{tabular}{|l|l|l|l|l|l|}
\hline $\begin{array}{l}\text { Initial } \\
\text { concentration of } \\
\text { the test solution } \\
(\% \mathrm{v} / \mathrm{v})\end{array}$ & $\begin{array}{l}\text { Number } \\
\text { of } \\
\text { mediums } \\
(\mu \mathrm{l})\end{array}$ & $\begin{array}{l}\text { Number of } \\
\text { bacterial } \\
\text { suspensions } \\
(\mu \mathrm{l})\end{array}$ & $\begin{array}{l}\text { The final } \\
\text { concentration of } \\
\text { the test solution } \\
(\% \mathrm{v} / \mathrm{v})\end{array}$ & $\begin{array}{l}\text { Colors before } \\
\text { being given } \\
\text { iodonitro- } \\
\text { tetrazolium } \\
(14 \mu \mathrm{l})\end{array}$ & $\begin{array}{l}\text { Color after } \\
\text { being } \\
\text { iodonitro- } \\
\text { given }\end{array}$ \\
\hline 1,25 & 200 & 200 & 0,25 & Kuning jernih & Kuning jernih \\
\hline 0,63 & 200 & 200 & 0,125 & Kuning jernih & Kuning jernih \\
\hline 0,32 & 200 & 200 & 0,06 & Kuning keruh & Merah \\
\hline 0,16 & 200 & 200 & 0,03 & Kuning keruh & Merah \\
\hline 0,08 & 200 & 200 & 0,0016 & Kuning keruh & Merah \\
\hline 0,04 & 200 & 200 & 0,008 & Kuning keruh & Merah \\
\hline 0,02 & 200 & 200 & 0,004 & Kuning keruh & Merah \\
\hline
\end{tabular}

From table 4 it is known that the test solution at $0.125 \%$ concentration does not turn red or remain clear yellow after being given an indicator iodonitrotetrazolium. For analysis of this mechanism of antibacterial oil, used concentration of $1 \mathrm{MIC}$ and $2 \mathrm{MIC}$, that is equal to $0,125 \%$ and $0,25 \%(\mathrm{v} / \mathrm{v})$.

In table 4 shows that the test solution at a concentration of $0.125 \%$ does not turn red or yellow remains clear after beinggiven iodonitrotetrazolium indicator. For analysis of this mechanism of antibacterial oil, used concentration of 1 MIC and 2 MIC, that is equal to $0,125 \%$ and $0,25 \%(\mathrm{v} / \mathrm{v})$.

The results of the test by diffusion method to show that the essential oil has antibacterial activity against the five test bacteria with different obstacles. Bacillus subtilis bacteria is the most sensitive bacteria to essential oil of lime leaf because it forms the largest diameter of resistance compared to other bacteria at concentration $50 \%$, so this bacterium is used in further research. The essential oil of lime leaves is effective in inhibiting the growth of Bacillus subtilis and these results are supported by MIC testing. In the test with the tube dilution method obtained MIC value of essential oil of $0.125 \%$. It is known from the absence of color change to red in $0.125 \%$ concentration test solution after being given $14 \mu \mathrm{l}$ iodonitrotetrazolium indicator.

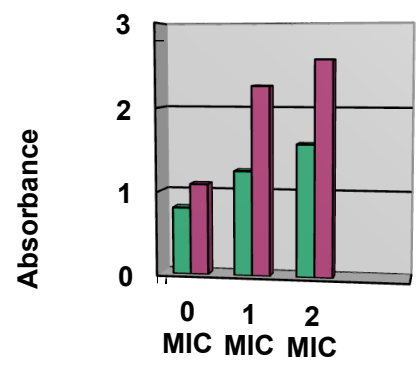

a Absorbance on $260 \mathrm{~nm}$ Absorbance on $280 \mathrm{~nm}$

Figure 2. Level of leakage of protein and nucleic acids of S. aureus in some concentrations of essential oil of lime 
e. Leakage of Proteins and Nucleic Acids

Provision of essential oils of lime leaves at several MIC doses resulted in cell damage observed in the presence of leakage of proteins and nucleic acids from bacterial cells. The essential oil of lime leaves causes cell leakage to be observed in the presence of increased absorbance values at $260 \mathrm{~nm}$ and $280 \mathrm{~nm}$ wavelengths. Compounds that give up absorption at $260 \mathrm{~nm}$ wavelengths are nucleic acids (RNA and DNA), whereas at $280 \mathrm{~nm}$ wavelengths are identified as proteins. From Figure 2, it can be seen that the administration of essential oil of lime leaves at concentrations of 1 MIC to Bacillus subtilis led to an increase in absorbance of nucleic acids from 0.804 to 1.254 and at concentration 2 MIC increased absorbance to 1.579. Increased absorbance values of nucleic acids are in line with increased protein absorbance. When compared with the increased absorbance of nucleic acids the increased absorbance for the protein is higher. At 1 MIC concentration there was an increase in protein absorbance from 1.090 to 2,260 or increased about twice and at concentration $2 \mathrm{MIC}$, the absorbance increased to 2.571 .

\section{f. Leakage of Proteins and Nucleic Acids}

Provision of essential oils of lime leaves at several MIC doses resulted in cell damage observed in the presence of leakage of proteins and nucleic acids from bacterial cells. The essential oil of lime leaves causes cell leakage to be observed in the presence of increased absorbance values at $260 \mathrm{~nm}$ and $280 \mathrm{~nm}$ wavelengths. Compounds that give up absorption at $260 \mathrm{~nm}$ wavelengths are nucleic acids (RNA and DNA), whereas at $280 \mathrm{~nm}$ wavelengths are identified as proteins. From Figure 2, it can be seen that the administration of essential oil of lime leaves at concentrations of 1 MIC to Bacillus subtilis led to an increase in absorbance of nucleic acids from 0.804 to 1.254 and at concentration 2 MIC increased absorbance to 1.579. Increased absorbance values of nucleic acids are in line with increased protein absorbance. When compared with the increased absorbance of nucleic acids the increased absorbance for the protein is higher. At 1 MIC concentration there was an increase in protein absorbance from 1.090 to 2,260 or increased about twice and at concentration $2 \mathrm{MIC}$, the absorbance increased to 2.571 .

\section{g. Leakage of Metal Ions}

Provision of essential oil of lime leaves at MIC concentrations to Bacillus subtilis causes cellular damage and the release of $\mathrm{Ca}^{2+}$ and $\mathrm{K}^{+}$ions from cells, as shown in Figure 3. From Figure 3 it was shown that giving of lime leaf at the concentration of 1 MIC and 2 MIC caused the release of $\mathrm{Ca}^{2+}$ content from cell. At $1 \mathrm{MIC}$ concentration $\mathrm{Ca}^{2+}$ ions came out $7.5 \%$ and at concentration $2 \mathrm{MIC}$ increased to $21,4 \%$ compared to control. Provision of essential oils also causes the release of $\mathrm{K}^{+}$ions from bacterial cells. At concentration $1 \mathrm{MIC}$, the release of $\mathrm{K}^{+}$ ion was $72 \%$ and at concentration 2 MIC release $\mathrm{K}^{+}$ion increased to $161 \%$ compared to control. As the concentrations of essential oils are used, more and more $\mathrm{Ca}^{2+}$ and $\mathrm{K}^{+}$ions are released from Bacillus subtilis bacterial cells.
An increase in absorbance value occurring either for nucleic acids or proteins corresponds to the concentration of MICs that are contacted to bacteria. The higher the concentration of MIC given then the leakage of cellular metabolites both protein and nucleic acid is increasing. The release of metal ions from bacterial cells signifies the presence of antibacterial activity that causes damage to the bacterial cytoplasmic membrane. An increase in the release of $\mathrm{K}^{+}$ions in bacteria is an indication of impairment of membrane permeability [13]. $\mathrm{Ca}^{2+}$ ion serves to maintain the stability of the bacterial membrane, in the presence of ion leakage then the stability of the membrane will be disrupted and can lead to bacterial death [15].

\section{h. Changes in Cell Morphology Bacillus subtilis}

Provision of essential oils at concentrations of 1 MIC and 2 MIC to Bacillus subtilis led to cell morphological changes that could be observed with SEM, as shown in Figure 4. Figure 3 shows the difference between control cells (untreated or image 3a) with cell treatment results. Bacillus subtilis is normally shaped with a smooth surface as shown in Figure 3a. giving essential oil of lime leaves at 1 MIC resulted in a morphological change of Bacillus subtilis that cells had shrinkage, elongated and the cell surface became coarse (figure $3 \mathrm{~b}$ ). Provision of essential oils at higher doses of $2 \mathrm{MIC}$, leading to the formation of clear holes on the cell surface of Bacillus subtilis (3c).

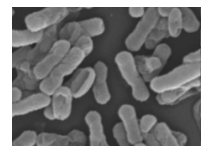

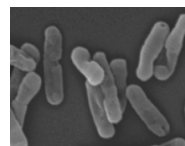

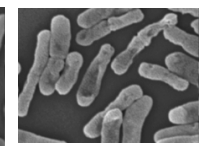

$\mathrm{c}$
Figure 3. Cell morphology B. Control subtilis (a), cell B. Subtilis after treatment with essential oils 1 MIC (b) and cell B. Subtilis after treatment with essential oil 2 MIC (c) $(20,000$ times magnification).

The antibacterial activity of essential oil of lime leaves can be affected by the components contained in the essential oil. Based on its chemical structure, the main components contained in the essential oil are the monoterpenes hydrocarbon (limonene), oxygenated monoterpenes (geranial, neral, citronellal) and sesquiterpenes (kariofilena). The terpenes have been widely reported to have antimicrobial activity, both against Gram-positive bacteria, Gram-negative bacteria and fungi [16]. Limonene is a nonpolar (hydrophobic) cyclic hydrocarbon compound monoterpenes while geranial, neral and citronellal are semipolar (hydrophilic) oxygenated oxygenated compounds. This is because the three compounds contain aldehid groups. The aldehyde group in the volatile oil is a semi-polar compound which is hydrophilic $[17,18]$.

Geranial and neral include weak acid groups that play a role in membrane permeability. These components can interact with the cell membrane, where the component is dissolved in the phospholipid layer and bonded between the fatty acid chain. This process can cause membrane instability, increased membrane fluidity and alter membrane permeability $[17,18]$ Membrane permeability changes can lead to leakage of ions, proteins and nucleic 
acids. The essential oil of lime leaves causes leakage of $\mathrm{Ca}^{2+}$ and $\mathrm{K}^{+}$ions as shown in Figure 3. Leakage of proteins and nucleic acids also occurs after administration of essential oils to Bacillus subtilis as seen in Fig. 2. Many cyclic hydrocarbon compounds are toxic to microorganisms [19]. This compound may cause disturbance to the peptidoglycan part of the cell wall so that polar compounds may enter and pass through the cell wall. This is due to the similarity of nonpolar (hydrophobic) properties between cyclic hydrocarbons and peptidoglycan from cell walls.

Characteristics of essential oils are able to bind to lipids in the cell membrane of bacteria thus affecting cell structure and membrane permeability [20]. From the SEM results it appears that Bacillus subtilis cells are normal (control) rod-shaped with a smooth surface. Treatment with the essential oil of 1 MIC causes a change of membrane structure when compared to the control cell. Bacillus subtilis cells elongate, the surface of the cell contracts and becomes coarse. With the provision of essential oils 2 MIC there is more damage to the cell that is the formation of holes in the cell surface so that the components in the cytoplasm (such as proteins, nucleic acids and metal ions) will come out of the cell.

Bacillus subtilis is one of the bacteria that can form endospores in poor condition. The endospores are highly resistant to heat, dryness and chemicals including essential oils chemical components. This will affect the extent of damage to the bacterial cell, which in the administration of 2 MIC only forms a hole in the cell surface that causes cell leakage. The existence of such leak can lead to death in bacterial cells. This is supported by cell leak analysis results in both leakage of ions, as well as leakage of proteins and nucleic acids (Figures 2 and 3).

Synergistic processes occur between the components of volatile essential oils with hydrophilic components. Hydrophobic compounds such as limonene and caryophilene interact with hydrophobic peptidoglycan while hydrophilic chemical components such as geranial, neral and citronellal interact with phospholipids in the cytoplasmic membrane. Furthermore, the hydrophobic essential oil components interact with fatty acids from the hydrophobic phospholipids. This process will disrupt the membrane permeability to facilitate all the essential oil chemical components entering the cytoplasmic membrane. Accumulation of chemical components in the membrane will change the structure and function of the membrane. This accumulation will cause membrane permeability changes so that the components contained in the cytoplasm will come out and bacterial cell death occurs.

\section{Conclusion}

1. Lime leaves (Citrus aurantifolia Swingle) contains about $0.4 \%(\mathrm{v} / \mathrm{w})$ of essential oils and consists of 40 chemical components with five main components, namely geranial $(10.39 \%)$, limonene $(10.2 \%)$, neral $(8.94 \%)$, kariofilena $(5.72 \%)$ and citronellal (5.41\%).

2. Essential oil of lime leaf has antibacterial activity against Staphylococcus aureus bacteria, Staphylococcus epidermidis, Bacillus subtilis, Micrococcus luteus and Escherichia coli. The MIC values obtained from the essential oils of Bacillus subtilis bacteria were $0.125 \%(\mathrm{v} / \mathrm{v})$.

3. Essential oil of lime leaves can lead to the occurrence of plasmolysis in bacteria Bacillus subtilis. This occurs through the destruction of bacterial cell membranes resulting in leakage of cells that can be observed in the presence of leakage of cellular metabolites, ie proteins and nucleic acids and leakage of metal ions $\mathrm{K}^{+}$and $\mathrm{Ca}^{2+}$.

\section{References}

[1] Chan M., Statement by WHO Director-General, 6 April $2011^{\prime}$

[2] Enejoh OS, Ogunyemi IO, Bala MS, Oruene IS, Suleiman $\mathrm{MM}$, et al. Ethnomedical Importance

of Citrus Aurantifolia (Christm) Swingle. The Pharma Innovation Journal (2015) 4: 01-06

[3] Deshpande SN Preliminary phytochemical analysis and in vitro investigation of antibacterial activity of Acacia nilotica against clinical isolates. Journal of Pharmacognosy and phytochemistry (2013) 1:23-27.

[4] J. D Sauer, Historical Geography oPlants Crop- $\alpha$ Select Roster, CRC Press, Boca Raton, Florida. 1993.

[5] J. Lawless, The Illustrated Encyclopedia of Essential Oils Rockport MA, Element Books, 1995, pp: 56-66

[6] W.B. Sinclair, "The Biochemistry and Physiology of the Lemon and other Citrus Fruits," Division of Agriculture and Natural Recources, University of California, Fremont, 1984, p.946.

[7] Mt. Jawaharlal, T. Thangaraj and Irulappan, "A Note on the Post Harvest Qualities of Acid Lime, "South Indian Hort, Vol. 40. No. . 1992, pp. 229-230

[8] S. V. Hitalmani and M. M. Rayo, " Studies on Changes in Physical Parameters of the Developing Kagzi Lime (C. aurantifolia) Fruits," South Indian Hort, Vol. 24, No. 3, 1970, pp. $122-126$

[9] R. K. Soost and J. W. Cameron, "Fruit Characters in Young Trees of Long-Established Nucellar Lines," Proc.2nd Conf. Intern. Org. Citrus Virol., 1961, pp. 8-14.

[10] P. Koehler-Santos, A. L. Dornelles and L. B. Freitas, "Characterization of Mandarin Citrus Germplasm from Southern Brazil by Morphological and Molecular Analyses," Pesquisa Agropecuária Brasileira, Vol. 38, No. 7, 2003, pp. 797-806.

[11] D. Q. Fang and M. L. Roose, "Identification of Citrus Cultivars with Inter-Simple Sequence Repeat Markers," Theoretical and Applied Genetics, Vol. 95, 1997, pp. 408417.

[12] Carson, Christine $F$ et al. Mechanism of Action of Melaleuca alternifolia (Tea Tree) Oil on Staphylococcus aureus Determined by Time-Kill, Lysis, Leakage, and Salt Tolerance Assays and Electron Microscopy. Antimicrobial Agent and Chemotherapy 6, 2002. pp1914-1920.

[13] Cox SD, C.M.Mann, J.L.Markham, H.C.Bell, J.E.Gustafson, J.R.Warmington and S.G.Wyllie.. 2000. The Mode of Antibacterial action of The Essential Oil of Melaleuca alternifolia (tea tree oil). Journal of Appl Microbiology 88 : 170-175.

[14] Fadel, HM. 1991. Comparison Studies on Leaf Oils of Egyptian Citrus Varieties. Journal of Islamic Academy of Sciences : 196-199.

[15] Suliantari. Aktivitas Antibakteri dan Mekanisme Penghambatan Ekstrak Sirih Hijau (Piper bettle Linn) Terhadap Bakteri Patogen Pangan. Disertasi. Sekolah Pascasarjana IPB. Bogor. (2009. bahasa)

[16] Trombetta D, A Saija, G Bisignano, S Arena, S Caruso, G Mazzanti, N Ucella and F castelli. 2005. Mechanisms of 
Antibacterial Action of Three Monoterpenes. Antimicrobial Agent and Chemoterapy, 49(6), pp. 2474-2478.

[17] Miksusanti, Betty Sri Laksmi, Bambang Pontjo dan Gatot Tri Mulyadi. 2008.Kerusakan Dinding Sel Escherichia coli K1.1 Oleh Minyak Atsiri Temu Kunci (Kaempferia pandurata). Berita Biologi $9: 1-8$.

[18] Miksusanti, Betty Sri Laksmi, Rizal Syarief, Bambang Pontjo dan Gatot Tri Mulyadi. 2009. Antibacterial Activity of Temu Kunci Tuber (Kaempheria pandurata) Essential
Oil against Bacillus cereus. Medicinal Journal Indonesia 18 : pp. 10-17. (bahasa)

[19] Sikkema J, AM Jan, Bont de, B Poolman. Interactions of Cyclic Hydrocarbons with Biological Membranes. Journal of Biological Chemistry 269, 1994., pp.8022-8028.

[20] Prabuseenivasan S, M. Jayakumar and S. Ignacimuthu.. In vitro Antibacterial Activity of Some Plants Essential oils. BMC Complementary and Alternative Medicine 20066 : 39. 
